\title{
SURVEY AND POPULATION FLUCTUATIONS OF COMMON INSECT PESTS AND THEIR PREDATORS ON TWO MEDICINAL PLANT SPECIES AT FAYOUM GOVERNORATE, EGYPT. Solaiman, R. H. A. Department of plant protection, Faculty of Agriculture, Fayoum Univ., Egypt.
}

\section{ABSTRACT}

Thirteen species of insect pests belong to eight families and five orders were recorded on Calendula plants. Nesidocoris tenuis Reut. While twelve insect pests belong to nine Families under six orders were recorded On chamomile plants. The chrysanthemum fly, Trupanea stellata (F.) was the highest in population followed by Lygus gomellatus $\mathrm{H}$. S. and Nysius graminicolus K.

Concerning the population fluctuations for the dominant insects pests, it found that $N$. tenuis had six peaks per season. The highest peaks were recordrd at the $2^{\text {nd }}$ week of April and the end of March for $1^{\text {st }}$ and $2^{\text {nd }}$ seasons, respectively. For Empoasca decipiens Paoli, detected four peaks in the $1^{\text {st }}$ season and five peaks in the $2^{\text {nd }}$ season. The highest peaks were recorded individuals/50 double sweep net strokes in the $2^{\text {nd }}$ week of April and in the $3^{\text {rd }}$ week of March. for $1^{\text {st }}$ and $2^{\text {nd }}$ seasons respectively. On chamomile, Lygus gomellatus had 5 peaks in the $1^{\text {st }}$ season and only four peaks in the $2^{\text {nd }}$ season. N. graminicolus, showed six peaks in the $1^{\text {st }}$ season and 5 peaks in the $2^{\text {nd }}$ season. The highest peaks were at the $1^{\text {st }}$ week of Dec. and the $2^{\text {nd }}$ week of Dec. for $1^{\text {st }}$ and $2^{\text {nd }}$ seasons. Aphids had four peaks in both study seasons, the highest peaks found in the last week of March and $3^{\text {rd }}$ week of Feb. for $1^{\text {st }}$ and $2^{\text {nd }}$ seasons, respectively. Also, population density of $T$. stellata recorded five peaks for each.

On the other hand, five species of predatory insects belong to four orders (Coleoptera, Hemiptera, Neuroptera and Diptera), were recorded in the first and $2^{\text {nd }}$ seasons on chamomile and calendula plants, respectively. Population density of predators showed that, Orius spp. was the most dominant predator, while the dipterous predators showed the lowest population.

Keywords: Calendula officinalis, Matricaria recutita; insect pests; Nesidocoris tenuis ; Nysius graminicolus ; Trupanea stellata Population dynamics

\section{INTRODUCTION}

The economic importance of Calendula and Chamomile plants:

Marigold plants, Calendula and Chamomile (German chamomile) Matricaria recutata L., are a perennial or annual plants that belong to family Asteraceae. As medicinal plants, Calendula flowers (Calendula officinalis L.), were considered beneficial for reducing inflammation, wound healing and as an antiseptic. It was used to treat various skin diseases, ranging from skin ulcerations to eczema. Internally, the soothing effects of Calendula have been used for stomach ulcers and inflammation. The chamomile has been traditionally considered to be antispasmodics, carminatives, diaphoretics, sedatives and stomachic. These plants have been used as a folk remedy against asthma, colic, fevers, inflammations and cancer (Foster et al., 1980; 
Gardiner, 1999). The herb was used to treat insomnia, back pain, neuralgia, rheumatism, skin conditions, indigestion, flatulence, headaches, and gout (Berry, 1995).

The insect pests and predators associated with Calendula and Chamomile plants:

These plants are attacked by several insect pests. In Egypt, El-Dessoki et al. (1976) reported that the tomato bug, Nesidocoris tenuis (Reut.) attacks many ornamental plants including C. officinalis. El-Gendi (1988) in Egypt, recorded 14 insect species on $C$. officinalis. The most common species as pests were N. tenuis, Nysus cymoides Schill., Myzus persicae (Sulzer) and Balclutha hortensis (Lindberg). Also she recorded 15 insects included seven sap-suckers, seven predators and one parasites on German chamomile, where the common insect pests were $M$. persicae, $N$. cymoides, $L$. gomellatus and $N$. tenuis. Chamomile plants are known to harbor many species of insects and mites including M. persicae, Aphis gossypii (Glover), E. decipiens, and N. cymoides (Etman et al., 1990; Rahil, 2005). In Italy, at least 26 insect pests belonging to 13 families and five orders are associated with common chamomile. The majority of the pests result in feeding damage on reproductive or vegetative organs (those under Thysanoptera and Heteroptera, including the Thripidae, Miridae, Pentatomidae and Pseudococcidae families), whereas others cause erosion or tunnels on heads (Noctuidae), leaves (beetles) or roots (Elateridae) (Conti, 2003). Yarmand et.al. (2006) in Iran, mentioned that the aphids have been the main pests associated with medicinal plants such chamomile, marigold and artichoke. In Hungary, True bugs, Nysius senecionis (Schilling) and Lygus spp. occurred on chamomile in high relative dominance. All other species of true bugs occurred only in very small number. El-Gendi (2007) in Egypt, recorded eighteen insect species on marjoram and chamomile. $N$. cymoides, Nezara viridula L., L. gomellatus, N. tenuis, B. horttensis, E. decipiens, Trupanea stellata Fuessly, $M$. persicae and $A$. gossypii were the main insect pests on chamomile. The seed bug species Metopoplax origami Kol., and plagiognathus chrysanthemi Wolff, are oligophagous species specialized on asteraceans in Hungary. Chamomile is the most one of all investigated medicinal and aromatic plants on which the damage by true bugs seems to be most important. (Redei, 2007). The present work aims to study the survey and population fluctuations of common insect pests and their predators associated on Calendula and Chamomile plants:

\section{MATERIALS AND METHODS}

The study was carried out in a private Calendula and chamomile fields ( each about one feddan $=4200 \mathrm{~m}^{2}$ ) located at yousef El-Seddek district, Fayoum governorate, Egypt for two successive seasons 2012/13 and $2013 / 14$. No insecticides were applied in these fields throughout the study period. The surrounding adjacent habitats of Calendula and chamomile plantations were represented by winter crops (as alfalfa wheat). After one month of transplanting sweeping net sampling technique was applied for 
surveying the insect pests. Fifty double strokes were randomly taken in an axial manner. Samples were collected in a polyethylene bags and transferred to laboratory. To kill insects, piece of cotton moistened with chloroform put in each sample and left for 15 minutes. The sample was emptied in petri dish $(12 \mathrm{~cm}$ in diameter) and cleaned from plant residues. Then it was examined under stereomicroscope to separate and count the major insect pests. This process was performed at weekly intervals throughout the entire period of investigation.

\section{Statistical analysis}

Simple correlation and regression values between the number of individuals of each species and the weekly means of the tested weather factors (temperature and \% $\mathrm{RH}$ ) were obtained according to correlation and regression analysis SPSS 2000, version 11.

\section{RESULTS AND DISCUSSION}

\section{I- Calendula officinalis}

\section{1- Survey}

Results of survey of insect pests on Calendula officinalis plants were summarized in Table (1). Data revealed that 13 insect pests were recorded on C. officinalis plants. These pests belong to eight families and five orders. Also, they included seven species as piercing sucking insects and five species as foliage and flower feeders. N. tenuis was the most abundant (1679 and 2038 individuals) followed by $E$. decipiens (471 and 501 individuals) during $1^{\text {st }}$ and $2^{\text {nd }}$ seasons, respectively.

2- Population fluctuations of economically important species:

\section{a- The tomato bug, $N$. tenuis}

In the first season, as shown in Table (2), this insect pest started appearance in samples from the $4^{\text {th }}$ week of Nov. and lasted to the third week of April. It had six peaks per season; by the $4^{\text {th }}$ week of Dec, the $1^{\text {st }}$ week of Jan. , the $3^{\text {rd }}$ week of Jan., the $2^{\text {nd }}$ week of Feb., the $2^{\text {nd }}$ week of March and the $1^{\text {st }}$ week of April with population densities of 95, 120, 125, 72, 114 and 248 individuals / 50 double sweep net strokes. Concerning the second season, the pest took the same trend, where it showed six peaks. 
Table (1): survey of insect pests infesting Calendula plants at Fayoum Gvernorate, Egypt. during 2012/13 and 2013/14 seasons.

\begin{tabular}{|c|c|c|c|c|c|}
\hline \multirow[t]{2}{*}{ Order } & \multirow{2}{*}{ Family } & \multirow[t]{2}{*}{ Common name } & \multirow{2}{*}{ Scientific name } & \multicolumn{2}{|c|}{$\begin{array}{l}\text { Total no. of } \\
\text { individuals }\end{array}$} \\
\hline & & & & $1^{\text {st }}$ season & $2^{\text {nd }}$ season \\
\hline \multirow{5}{*}{ Hemiptera } & \multirow{2}{*}{ Miridae } & Tomato bug & Nesidocoris tenuis Reut. & 1679.0 & 2038.0 \\
\hline & & Mirid bug & Lygus gomellatus H. S & 178.0 & 75.0 \\
\hline & \multirow[t]{2}{*}{ Lygaeidae } & Plant bug & $\begin{array}{c}\text { Pseudatomoscelis seriatus } \\
\text { Reuter }\end{array}$ & 14.0 & 23.0 \\
\hline & & Marigold bug & Nysius graminicolus K. & 35.0 & 41.0 \\
\hline & Pentatomidae & Stink bug & Nezara viridula $\mathrm{L}$. & 1.0 & 0.0 \\
\hline \multirow{2}{*}{ Homoptera } & \multirow{2}{*}{ Cicadelledae } & Cotton leafhopper & Empoasca decipiens Poali & 471.0 & 501.0 \\
\hline & & Sesame hopper. & Orosius albicinctus Distant & 3.0 & 15.0 \\
\hline \multirow{2}{*}{ Lepidoptera } & \multirow{2}{*}{ Noctuidae } & Bollworm & Heliothis paltigera (D\&S) & 3.0 & 12.0 \\
\hline & & Cotton leaf worm & Spodoptera littoralis Boisduval & 2.0 & 2.0 \\
\hline \multirow{2}{*}{ Diptera } & Lriomyzidae & Alfafa leafminer & Leriomyza trifolii Burgess & 33.0 & 30.0 \\
\hline & Tephritidae & Chamomile fly & Trupanea stellata F. & 40.0 & 3.0 \\
\hline Orthoptera & Acrididae & Rice grasshopper & Aiolopus stripins Latreille & 4.0 & 0.0 \\
\hline
\end{tabular}

The first peak was found in the beginning of Dec. with 38 individuals / 50 double sweep net strokes, while the second peak (68 individuals / 50 double sweep net strokes) was in the $4^{\text {th }}$ week of Dec. The $3^{\text {rd }}, 4^{\text {th }}$ and 5 th peaks were recorded in the $3^{\text {rd }}$ week of Jan. in the $3^{\text {rd }}$ week of Feb., in the $3^{\text {rd }}$ week of March, respectively. The last and highest peak was found at the beginning of April with 483 individuals / 50 double sweep net strokes. ElGendi (1988) stated that $N$. tenuis had three broods during the period from late march to mid May. Statistical analysis showed that the simple correlation was insignificant positive between mean temperature and population density of $N$. tenuis in the both study years $(r=0.332$ and 0.188$)$, while it was insignificant negative with mean relative humidity in the $1^{\text {st }}$ and $2^{\text {nd }}$ years $(r=-0.185$ and -0.401$)$.

\section{b- The potato leafhopper, E. decipiens.}

Data in Table (2) indicated that this insect pest increased gradually to record four peaks through the first season of study. The $1^{\text {st }}$ peak in the $3^{\text {rd }}$ week of Dec., in the $2^{\text {nd }}$, in the $1^{\text {st }}$ week of Jan., in the $3^{\text {rd }}$ in the $1^{\text {st }}$ week of March, and the $4^{\text {th }}$ in the $2^{\text {nd }}$ week of April with population density of 24,36 , 55 and 77 individuals/50 double sweep net strokes, respectively. Then the population decreased gradually until the end of crop in mid of April. In the second season, as shown in Table 2, the pest appeared in the end of Nov., and population of the pest showed five peaks. The $1^{\text {st }}$ peak in the beginning of Dec., the $2^{\text {nd }}$ in the end of Dec., the $3^{\text {rd }}$ in the end of Jan., the $4^{\text {th }}$ in the $4^{\text {th }}$ week of Feb., and the $5^{\text {th }}$ in the $2^{\text {nd }}$ week of April with 6.0, 19.0, 8.0, 221 and 29 individuals/50 double sweep net strokes, respectively. Statistically, the effect of mean weather factors (mean temperature and \% $\mathrm{RH}$ ) on population density of $E$. decipiens was insignificant negative in the both study seasons, except with mean temperature in the $1^{\text {st }}$ season where it was significant positive $(r=0.0 .421)$. 
Table 2. Population fluctuations of $N$. tenuis and $E$. decipiens on Calendula officinalis at Fayoum Governorate, during 2012/2013 and 2013/2014 seasons.

\begin{tabular}{|c|c|c|c|c|c|c|c|c|c|}
\hline \multirow[b]{3}{*}{$\begin{array}{c}\text { Date of } \\
\text { inspection }\end{array}$} & \multicolumn{4}{|c|}{$2012 / 2013$} & \multicolumn{5}{|c|}{$2013 / 2014$} \\
\hline & \multicolumn{2}{|c|}{$\begin{array}{c}\text { No. of } \\
\text { individuals/50 } \\
\text { double strokes }\end{array}$} & \multicolumn{2}{|c|}{$\begin{array}{l}\text { Weather } \\
\text { factors }\end{array}$} & \multirow{2}{*}{ 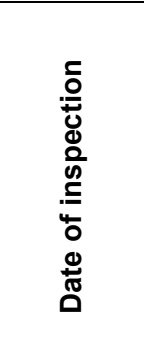 } & \multicolumn{2}{|c|}{$\begin{array}{c}\text { No. of } \\
\text { individuals/50 } \\
\text { double strokes }\end{array}$} & \multicolumn{2}{|c|}{$\begin{array}{l}\text { Weather } \\
\text { factors }\end{array}$} \\
\hline & 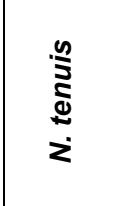 & $\begin{array}{l}\frac{n}{0} \\
\frac{0}{0} \\
\frac{0}{0} \\
\frac{d}{0} \\
\text { 山่ }\end{array}$ & 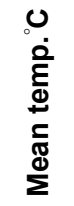 & $\frac{\frac{T}{\alpha}}{\frac{\alpha}{0}}$ & & 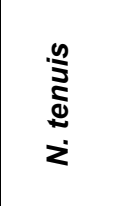 & 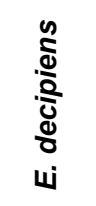 & 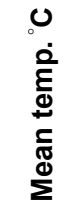 & $\frac{T}{\frac{T}{\alpha}}$ \\
\hline 19/11/012 & 0.0 & 4.0 & 17.4 & 56.0 & $18 / 11 / 013$ & 0.0 & 0.0 & 23.7 & 55.0 \\
\hline $26 / 11$ & 6.0 & 5.0 & 17.6 & 55.0 & $25 / 11$ & 13.0 & 5.0 & 22.9 & 57.0 \\
\hline $3 / 12$ & 9.0 & 7.0 & 16.7 & 54.0 & $2 / 12$ & 38.0 & 6.0 & 21.4 & 52.0 \\
\hline $10 / 12$ & 43.0 & 15.0 & 15.5 & 54.0 & $9 / 12$ & 15.0 & 0.0 & 21.2 & 52.0 \\
\hline $17 / 12$ & 61.0 & 24.0 & 15.0 & 49.0 & $16 / 12$ & 26.0 & 5.0 & 14.8 & 49.0 \\
\hline $24 / 12$ & 95.0 & 11.0 & 15.1 & 53.0 & $23 . / 12$ & 68.0 & 3.0 & 15.3 & 56.0 \\
\hline $31 / 12$ & 72.0 & 8.0 & 16.3 & 58.0 & $30 / 12$ & 61.0 & 19.0 & 16.8 & 54.0 \\
\hline $7 / 1 / 013$ & 120.0 & 36.0 & 15.2 & 57.0 & $6 / 1 / 014$ & 50.0 & 3.0 & 14.7 & 58.0 \\
\hline $14 / 1$ & 68.0 & 11.0 & 15.1 & 54.0 & $13 / 1$ & 36.0 & 0.0 & 14.1 & 57.0 \\
\hline $21 / 1$ & 125.0 & 2.0 & 14.6 & 52.0 & $20 / 1$ & 71.0 & 5.0 & 13.3 & 62.0 \\
\hline $28 / 1$ & 52.0 & 6.0 & 13.4 & 53.0 & $27 / 1$ & 28.0 & 8.0 & 14.0 & 51.0 \\
\hline $4 / 2$ & 20.0 & 1.0 & 14.7 & 48.0 & $3 / 2$ & 2.0 & 1.0 & 16.8 & 51.0 \\
\hline $11 / 2$ & 72.0 & 15.0 & 13.0 & 45.0 & $10 / 2$ & 55.0 & 6.0 & 16.5 & 57.0 \\
\hline $18 / 2$ & 47.0 & 18.0 & 19.5 & 49.0 & $17 / 2$ & 67.0 & 6.0 & 14.5 & 50.0 \\
\hline $25 / 2$ & 59.0 & 35.0 & 17.8 & 50.0 & $24 / 2$ & 40.0 & 10.0 & 16.5 & 45.0 \\
\hline $4 / 3$ & 84.0 & 55.0 & 16.9 & 53.0 & $3 / 3$ & 37.0 & 3.0 & 15.5 & 49.0 \\
\hline $11 / 3$ & 114.0 & 50.0 & 22.9 & 49.0 & $10 / 3$ & 59.0 & 114.0 & 17.2 & 49.0 \\
\hline $18 / 3$ & 96.0 & 9.0 & 21.1 & 52.0 & $17 / 3$ & 121.0 & 221.0 & 16.3 & 51.0 \\
\hline $25 / 3$ & 60.0 & 6.0 & 16.9 & 51.0 & $24 / 3$ & 54.0 & 35.0 & 18.8 & 50.0 \\
\hline $1 / 4$ & 82.0 & 36.0 & 18.5 & 48.0 & $31 / 3$ & 483.0 & 5.0 & 18.2 & 49.0 \\
\hline $8 / 4$ & 248 & 77.0 & 22.3 & 49.0 & $7 / 4$ & 48.0 & 29.0 & 20.2 & 49.0 \\
\hline $15 / 4$ & 68.0 & 33.0 & 22.1 & 46.0 & $14 / 4$ & 119.0 & 17.0 & 18.4 & 45.0 \\
\hline $22 / 4$ & 78.0 & 7.0 & 24.5 & 45.0 & $21 / 4$ & 547.0 & 0.0 & 21.7 & 44.0 \\
\hline Total & 1679.0 & 471.0 & - & - & Total & 2038.0 & 501.0 & - & - \\
\hline
\end{tabular}

\section{II- Chamomile}

\section{1-Survey}

Data in table 3 showed that twelve species of insect pests were found on chamomile plants. These pests, namely Lygus gomellatus H. S., Nysius graminicolus K.. Pseudotomoscelis seriatus Reuter; Nezara viridula L.; Empoasca decipiens paoli; Exitanus capicola Stal.; Aphis gossypii Glover; Myzus persicae Sulzer; Trichoplosia ni; Heliothis armegera F.; Thrips tabaci Lind; Trupanea stellata ( $F$.) belong to nine Families in six Orders. The chrysanthemum fly was the highest in population followed by the $L$. gomellatus and N. graminicolus. 


\section{2- Population fluctuations}

\section{a- Green bug, Lygus gomellatus:}

Data in Table (4) indicated that, this pest started to appear during the $4^{\text {rd }}$ week of Nov. The population showed five peaks of abundance in the first year of study, the $1^{\text {st }}$ peak in the beginning of Dec., the $2^{\text {nd }}$ in the end of December, the $3^{\text {rd }}$ in the $4^{\text {th }}$ week of Jan., the $4^{\text {th }}$ on $25^{\text {th }}$ Feb., and the $5^{\text {th }}$ in the $2^{\text {nd }}$ week of March with population density of 19.0, 28.0, 17.o, 103.0 and 318.0 individuals/ 50 double sweep net strokes, respectively. In the second season of investigation, data in Table (4), illustrated the population density of these insects was lower than that of the first season. The pest had only four peaks in the $2^{\text {nd }}$ week of Dec., $3^{\text {rd }}$ week of Feb., and the beginning \& ending of March, with population densities 11.0, 17.0, 24 and 53 individuals /50 double sweep net strokes.

Statistical analysis showed that the simple correlation was highly significant positive between mean temperature and population density of $L$. gomellatus in the $1^{\text {st }}$ year $(r=0.778)$, while it was significant negative with mean relative humidity in the $2^{\text {nd }}$ year $(r=-0.464)$.

Table 3. Insect pests recorded on chamomile plants during 2012/13 and 2013/14 seasons at yousef El-Seddik district , Fayoum Governorate, Egypt.

\begin{tabular}{|c|c|c|c|c|c|}
\hline \multirow[b]{2}{*}{ Order } & \multirow[b]{2}{*}{ Family } & \multirow[b]{2}{*}{ Common name } & \multirow[b]{2}{*}{ Scientific name } & \multicolumn{2}{|c|}{$\begin{array}{l}\text { Total no. of } \\
\text { individuals }\end{array}$} \\
\hline & & & & \begin{tabular}{|c|}
$1^{\text {st }}$ \\
season
\end{tabular} & $\begin{array}{l}2^{\text {nd }} \\
\text { season }\end{array}$ \\
\hline \multirow{4}{*}{ Hemiptera } & Miridae & Green bug & Lygus gomellatus H. S. & 1188.0 & 219.0 \\
\hline & \multirow[b]{2}{*}{ Lygaeidae } & \multirow{2}{*}{$\begin{array}{l}\text { Cotton } \\
\text { fleahopper }\end{array}$} & Nysius graminicolus $\mathrm{K}$. & 577.0 & 241.0 \\
\hline & & & $\begin{array}{c}\text { Pseudatomoscelis seriatus } \\
\text { Reuter }\end{array}$ & 89.0 & 116.0 \\
\hline & Pentatomidae & Green sting bug & Nezara viridula L. & 2.0 & 1.0 \\
\hline \multirow{4}{*}{ Homoptera } & \multirow{3}{*}{ Cicadellidae } & $\begin{array}{c}\text { Potato } \\
\text { leafhopper }\end{array}$ & Empoasca decipiens Paoli & 176.0 & 22.0 \\
\hline & & \multirow{2}{*}{$\begin{array}{c}\text { Sesame } \\
\text { Leafhopper }\end{array}$} & Orosius albicinctus Distant & 7 & 13 \\
\hline & & & Exitanus capicola Stal. & 5.0 & 3.0 \\
\hline & Aphidide & $\begin{array}{c}\text { Cotton aphids \& } \\
\text { peach green } \\
\text { aphids }\end{array}$ & $\begin{array}{l}\text { Aphis gossypii Glover\& } \\
\text { Myzus persicae Sulser }\end{array}$ & 256.0 & 622.0 \\
\hline diptera & Tephritidae & $\begin{array}{c}\text { chrysanthemum } \\
\text { fly }\end{array}$ & Trupanea stellata (F.) & 1426.0 & 705.0 \\
\hline \multirow[t]{2}{*}{ Lepidoptera } & \multirow[t]{2}{*}{ Noctuidae } & $\begin{array}{c}\text { Alfalfa } \\
\text { semilooper }\end{array}$ & Trichoplusia ni Hubner & 4.0 & 0.0 \\
\hline & & Cotton bollwom & Heliothis armigera $\mathrm{F}$. & 6.0 & 3.0 \\
\hline Coleoptera & Dermistidae & Cloth beetle & $\begin{array}{c}\text { Attagenus fasciatus } \\
\text { Thunberg }\end{array}$ & 26 & 40 \\
\hline Thysanoptera & Thripidae & Onion thrips & Thrips tabaci Lind. & 15.0 & 23.0 \\
\hline
\end{tabular}

\section{b- Nysius graminicolus}

As shown in Table (4), the pest in the first season started to appeared in samples from the $3^{\text {rd }}$ week of Nov . and lasted to the end of crop. It had six peaks; at the $1^{\text {st }}$ week of Dec, the $4^{\text {th }}$ week of Dec.; the $1^{\text {st }}$ week of Jan; the 
end of Jan.; the $3^{\text {rd }}$ week of Feb. and the $2^{\text {nd }}$ week of March with 85.0, 48.0, $76.0,12.0,26.0$ and 74.0 individuals/ 50 double strokes, respectively. In the second season, data in Table (4) revealed that the population density of $N$. graminicolus was much lower than those of the first season. It had five peaks. The first peak was found at the $4^{\text {th }}$ week of Nov. with 42.0 individuals / 50 double strokes. The second peak (highest) was in the $2^{\text {nd }}$ week of Dec. with 54.0 individuals / 50 double strokes. The $3^{\text {rd }}$ and $4^{\text {th }}$ peaks (22 and 14 individuals) recorded durin $4^{\text {th }}$ week of Dec. and $1^{\text {st }}$ week of Jan., respectively. The $5^{\text {th }}$ peak (lowest) was found in the $3^{\text {rd }}$ week of March with 5.0 individuals / 50 double strokes. El-Gendi (1988) mentioned that $N$. cymoides recorded three broods from late May to mid-July.

Statistically, the effect of mean weather factors on population density was insignificant positive in the both study seasons, except with \%RH in the $2^{\text {nd }}$ season where it was highly significant positive $(r=0.668)$.

\section{c- Aphids (Aphis gossypii \& Myzus persicae)}

Data in Table (4) revealed that these pest had four peaks per season. In the first season, peaks recorded in the $3^{\text {rd }}$ week of Jan., in the $1^{\text {st }}$ week of Feb., in the $1^{\text {st }}$ week of March, and in the last week of March, recording the highest peak (93 individuals / 50 double strokes) when the means of weather factors were $16.9{ }^{\circ} \mathrm{C}$ and $51.0 \% \mathrm{RH}$. Concerning the second season, population was higher and showed four peaks. The first peak was in the last week of Nov., the $2^{\text {nd }}$ in the $1^{\text {st }}$ week of Jan., the $3^{\text {rd }}$ in $3^{\text {rd }}$ week of Feb., and the $4^{\text {th }}$ in the $1^{\text {st }}$ week of March with population of $66,12,159$ and 133 individuals / 50 double weep net strokes respectively. El-Gendi (2007) found that $A$. gossypii had one peak in the first season and three peaks in the $2^{\text {nd }}$ season in mid Jan., mid Feb., and mid-April.

Statistical analysis showed that the relationship between population density of Aphis sp. and mean weather factors was insignificant negative in the both study seasons except with mean temperature in the $1^{\text {st }}$ season where it was insignificant positive $(r=0.149)$.

\section{d- Chrysanthemum fly, Trupanea stellata (F.)}

Data obtained in Table (4) demonstrated that, in the first season, the chrysanthemum fly appeared in chamomile samples from the $3^{\text {rd }}$ week of Nov. and continued to the beginning of April. It had five peaks per season. The first peak in the beginning of Dec, the $2^{\text {nd }}$ in the $1^{\text {st }}$ week of Jan. the $3^{\text {rd }}$ and highest peak was in the $1^{\text {st }}$ week of $\mathrm{Feb}$, the $4^{\text {th }}$ and $5^{\text {th }}$ peaks were recorded by end of Feb., and the end of March with population densities of $58,244,73,78$ and 123 , respectively. In the second season, the population densities of chrysanthemum fly showed the same trend of the first season, where it had five peaks. The first peak was found by the last week of Nov. with 43 flies / 50 double sweep net strokes, while the highest peak was in the last week of March with 61 flies / 50 double sweep net strokes.

Concerning statistical analysis, the effect of mean temperature and \% $\mathrm{RH}$ on population density of $T$. stellata, was insignificantly negative except with the mean relative humidity in the $1^{\text {st }}$ season where the simple correlation was insignificantly positive ( $r=0.482)$. El-Gendi (2007) stated that the correlation between the population densities and weather factors was 
insignificantly negative in the $1^{\text {st }}$ season and insignificantly positive in the $2^{\text {nd }}$ season.

III- predators

1-Survey of predatory species associated with chamomile and calendula crops:

As shown in Table (5), five species of predatory insects belong to four orders with a total number of 452 and10 individuals in the first season, and 382 and 29 in the $2^{\text {nd }}$ season on chamomile and calendula crops, respectively. On chamomile plants, Orius sp. was the most dominant predator in the two seasons of the study where it represented $(44.24 \%)$ in the first season and $(72.77 \%)$ in the $2^{\text {nd }}$ season. Syrphus sp. was the lowest predator in the population of both seasons and crops.

Table 4. Population fluctuations of some insect pests infesting chamomile plants in the field at Fayoum Governorate during 2012/2013 and 2013/2014 seasons.

\begin{tabular}{|c|c|c|c|c|c|c|c|c|c|c|c|c|c|}
\hline \multicolumn{7}{|c|}{$2012 / 2013$} & \multicolumn{7}{|c|}{$2013 / 2014$} \\
\hline \multirow[b]{2}{*}{ 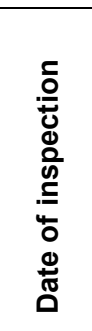 } & \multicolumn{4}{|c|}{$\begin{array}{c}\text { No. of individuals/50 } \\
\text { double strokes }\end{array}$} & \multicolumn{2}{|c|}{$\begin{array}{l}\text { Weather } \\
\text { factors }\end{array}$} & \multirow[b]{2}{*}{ 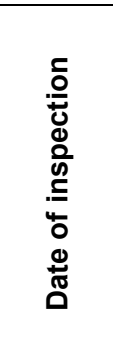 } & \multicolumn{4}{|c|}{\begin{tabular}{|c|}
$\begin{array}{c}\text { No. of individuals/50 } \\
\text { double strokes }\end{array}$ \\
\end{tabular}} & \multicolumn{2}{|c|}{$\begin{array}{l}\text { Weather } \\
\text { factors }\end{array}$} \\
\hline & 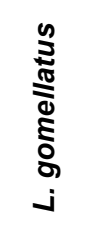 & 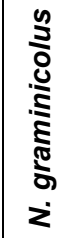 & $\frac{\frac{c}{0}}{\frac{0}{2}}$ & 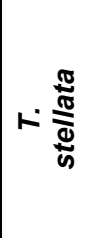 & 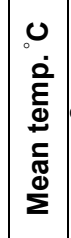 & $\% R H$ & & 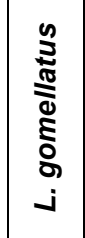 & 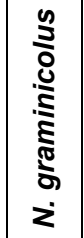 & $\frac{\frac{0}{0}}{\frac{0}{2}}$ & $-\frac{\frac{\pi}{\pi}}{\frac{\pi}{5}}$ & 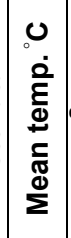 & $\% R H$ \\
\hline 19/11 & 12.0 & 10.0 & 0.0 & 3.0 & & 56.0 & & 0.0 & 22.0 & .0 & 2.0 & & 55.1 \\
\hline $26 / 11$ & 4.0 & 25.0 & 0 & 16.0 & 70 & 55.0 & $25 / 1$ & .0 & 2.0 & 0.0 & r & & \\
\hline $3 / 12$ & 19.0 & 85.0 & 0 & 58.0 & 6.7 & 54.0 & $2 / 12$ & 7.0 & 7.0 & 28.0 & 30.0 & & \\
\hline $10 / 12$ & 11.0 & 54.0 & 3.0 & 51.0 & 15.5 & 54.0 & $9 / 12$ & 11.0 & 54.0 & 5.0 & 26.0 & & 2. \\
\hline $17 / 12$ & 10.0 & 30.0 & 2.0 & 25.0 & 15.0 & 49.0 & $16 / 1$ & 1.0 & 5.0 & 1.0 & 35.0 & & \\
\hline $24 / 12$ & 22.0 & 48.0 & 0.0 & 0 & $\mid 15.1$ & 53.0 & $23 . / 12$ & 0.0 & 22.0 & 9.0 & 28.0 & & 6.0 \\
\hline $31 / 12$ & 28.0 & 35.0 & 2.0 & 35.0 & 16.3 & 58.0 & $30 / 12$ & 0.0 & 1.0 & \begin{tabular}{|l|}
6.0 \\
\end{tabular} & 25.0 & & 4 \\
\hline $1 / 0$ & & & S & 0 & 15.2 & 57.0 & t/1/2014 & 0 & 14.0 & 12.0 & 53.0 & & \\
\hline $14 / 1$ & 20.0 & 25.0 & 6.0 & 88.0 & $\mid 15.1$ & 54.0 & $13 / 1$ & 0.0 & \begin{tabular}{|l|}
8.0 \\
\end{tabular} & \begin{tabular}{|l|}
8.0 \\
\end{tabular} & 20.0 & & 570 \\
\hline $21 / 1$ & 8.0 & 1. & 18.0 & 75.0 & 14.6 & 5 & 2 & 0.0 & & 0 & 10.0 & & \\
\hline $28 / 1$ & & & & 40 & & & 2 & 5.0 & & 0.0 & 34.0 & & \\
\hline $4 / 2$ & 9.0 & 7.0 & 12.0 & 73.0 & 14.7 & 48.0 & $3 / 2$ & 13.0 & 0.0 & 7.0 & 39.0 & & 51. \\
\hline $11 / 2$ & 8.0 & 3.0 & 80 & 6.0 & 130 & 4150 & & 14.0 & 1.0 & 14.0 & 46.0 & & \\
\hline $18 / 2$ & 76.0 & 26.0 & 4. & 29.0 & 19.5 & 549.0 & $17 / 2$ & 17.0 & 2.0 & 159.0 & 31.0 & & 50. \\
\hline $25 / 2$ & 103.0 & 12.0 & 9.0 & 78.0 & & 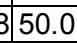 & $24 / 2$ & .0 & 2.0 & 79.0 & 38.0 & & \\
\hline $4 / 3$ & 97.0 & 17 & 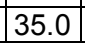 & 8.0 & & 9 & $3 / 3$ & 24.0 & 0 & 133.0 & 40.0 & & \\
\hline $11 / 3$ & 318.0 & 74.0 & 19.0 & 6.0 & 22.9 & 949.0 & $10 /$ & 15.0 & 1.0 & 63.0 & 44.0 & & \\
\hline $18 / 3$ & 0 & 16.0 & & & 21.1 & 150 & & 9.0 & 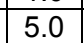 & 21.0 & 58.0 & & \\
\hline $25 / 3$ & 131.0 & \begin{tabular}{|l|}
8.0 \\
\end{tabular} & \begin{tabular}{|l|}
93.0 \\
\end{tabular} & 123.0 & 16.9 & 951.0 & $24 / 3$ & 39.0 & 2.0 & \begin{tabular}{|l|} 
\\
\end{tabular} & 61.0 & & 50. \\
\hline $1 / 4$ & 176.0 & 13.0 & 5.0 & 5.0 & 18.5 & 548.0 & $31 / 3$ & 53.0 & 15.0 & \begin{tabular}{|l|}
4.0 \\
\end{tabular} & 32.0 & 1 & 49. \\
\hline 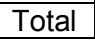 & 1400 & 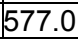 & 50 & 1426.0 & & & & 10 & y & $\mid 0<\angle$. & 705 & & \\
\hline
\end{tabular}


Table 5. Natural enemies inhapiting chamomile and calendula plants during 2012/13 and 2013/14 seasons at yousef El-Seddik district , Fayoum governorate, Egypt.

\begin{tabular}{|c|c|c|c|c|c|c|c|}
\hline \multirow[b]{3}{*}{ Order } & \multirow[b]{3}{*}{ Family } & \multirow[b]{3}{*}{$\begin{array}{l}\text { Common } \\
\text { name }\end{array}$} & \multirow[b]{3}{*}{ Scientific name } & \multicolumn{4}{|c|}{ No. of predators } \\
\hline & & & & \multicolumn{2}{|c|}{$1^{\text {st }}$ season } & \multicolumn{2}{|c|}{$2^{\text {nd }}$ season } \\
\hline & & & & 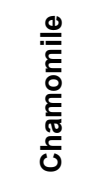 & $\begin{array}{c}\frac{\pi}{J} \\
\frac{0}{0} \\
\frac{0}{\pi} \\
\mathcal{J}\end{array} \mid$ & $\begin{array}{l}\frac{0}{\bar{E}} \\
\frac{0}{0} \\
\frac{E}{\sqrt{n}} \\
\frac{c}{U}\end{array}$ & $\begin{array}{l}\frac{\pi}{3} \\
\frac{0}{0} \\
\frac{c}{0} \\
0 \\
0\end{array}$ \\
\hline Coleopteran & Coccinelidae & Lady beetles & \begin{tabular}{|c|} 
Coccinella \\
undecimpunctata \\
Linnaeus
\end{tabular} & 51.0 & 0.0 & 41.0 & 6.0 \\
\hline Hemiptera & - & - & Orius sp. & 200.0 & 4.0 & 281.0 & 23.0 \\
\hline Neuroptera & chrysopidae & $\begin{array}{c}\text { Green } \\
\text { lacewing }\end{array}$ & $\begin{array}{c}\text { Chrysopa carnea } \\
\text { Stephen }\end{array}$ & 196.0 & 0.0 & 37.0 & 0.0 \\
\hline Diptera & Syrphidae & Hoverflies & Syrphus sp. & 5.0 & 6.0 & 23.0 & 0.0 \\
\hline Total & - & - & - & 452.0 & 10.0 & 382.0 & 29.0 \\
\hline
\end{tabular}

\section{2-Population density of the major predatory insects inhapiting} chamomile crop:

The population fluctuations of predators associated with chamomile plants were illustrated in Table (6).

\section{a- Orius spp.}

In the $1^{\text {st }}$ season, three peaks of Orius sp. were recorded at $1^{\text {st }}$ week of December, the $1^{\text {st }}$ week of February and the $3^{\text {rd }}$ week of March. The $2^{\text {nd }}$ peak was the highest ( 25 individuals / 50 double net strokes. In the second season, population density recorded four peaks at early-December, the $4^{\text {th }}$ week of December, $2^{\text {nd }}$ week of Jan and the $3^{\text {rd }}$ week of March. The $4^{\text {th }}$ peak was the highest ( 51 individuals / 50 double strokes.

\section{b- Coccinella undecimpunctata L. :}

Two peaks of $C$. undecimpunctata were recorded at $3^{\text {rd }}$ week of December and $2^{\text {nd }}$ week of January in the first season with 14.0 and 7.0 individuals $/ 50$ double net strokes, respectively. In the $2^{\text {nd }}$ season, date of peaks was early-December and the $3^{\text {rd }}$ week of February.

c- Chrysopa carnea (Steph.):

Numbers of $C$. carnea were generally low in the winter. the population density was high in the $1^{\text {st }}$ season compared with that of the $2^{\text {nd }}$ season. this predator had 3 peaks in the $1^{\text {st }}$ season in the third week of Jan., $3^{\text {rd }}$ week of February and the $2^{\text {nd }}$ week of of March. In the second season, it had only one peak in the $4^{\text {th }}$ week of February with 10 individuals / 50 double net strokes. El-Gendi (2007) mentioned that C. carnea was the dominant predator in the first season with one peak, while the dominant predator in the $2^{\text {nd }}$ season was C. undecimpunctata where it recorded two peaks, the $1^{\text {st }}$ one in the end of Jan., and the $2^{\text {nd }}$ in mid-April. 


\section{Acknowledgement}

I thank Prof. Dr. El-Sebaey I. I. A., head of Taxonomy Dept., Plant Protection Research Institute, ARC., Ministry of Agriculture, Dokki, Giza, Egypt for identifying hemipterous insects for me.

Table 6. Population fluctuations of predators inhapiting chamomile plants in the field at Fayoum Governorate during 2012/2013 and $2013 / 2014$ seasons.

\begin{tabular}{|c|c|c|c|c|c|c|c|c|c|c|c|}
\hline \multicolumn{6}{|c|}{$2012 / 2013$} & \multicolumn{6}{|c|}{$2013 / 2014$} \\
\hline \multirow[b]{2}{*}{ 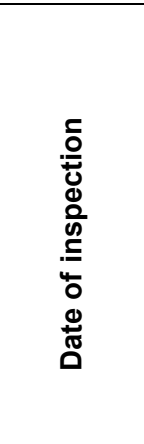 } & \multicolumn{3}{|c|}{$\begin{array}{c}\text { No. of } \\
\text { individuals/50 } \\
\text { double strokes }\end{array}$} & \multicolumn{2}{|c|}{$\begin{array}{l}\text { Weather } \\
\text { factors }\end{array}$} & \multirow[b]{2}{*}{ 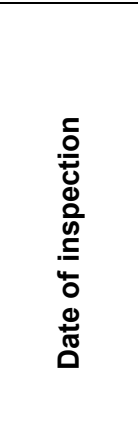 } & \multicolumn{3}{|c|}{$\begin{array}{c}\text { No. of } \\
\text { individuals/50 } \\
\text { double strokes }\end{array}$} & \multicolumn{2}{|c|}{$\begin{array}{c}\text { Weather } \\
\text { factors }\end{array}$} \\
\hline & 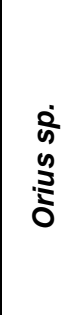 & 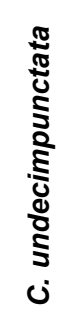 & 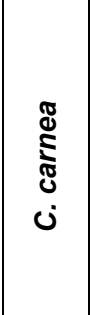 & 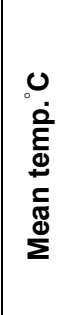 & $\frac{T}{\frac{T}{\alpha}}$ & & 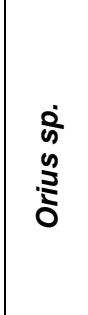 & 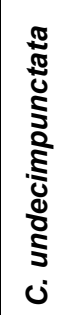 & 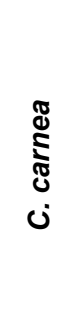 & 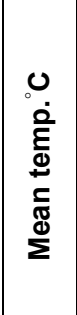 & $\frac{T}{\frac{T}{\alpha}}$ \\
\hline 19/11/012 & 0.0 & 0.0 & 1.0 & 17.4 & 56.0 & $18 / 11 / 013$ & 0.0 & 2.0 & 0.0 & 23.7 & 55.0 \\
\hline $26 / 11$ & 0.0 & 2.0 & 7.0 & 17.6 & 55.0 & $25 / 11$ & 13.0 & 3.0 & 2.0 & 22.9 & 57.0 \\
\hline $3 / 12$ & 10.0 & 2.0 & 2.0 & 16.7 & 54.0 & $2 / 12$ & 23.0 & 12.0 & 3.0 & 21.4 & 52.0 \\
\hline $10 / 12$ & 4.0 & 6.0 & 2.0 & 15.5 & 54.0 & $9 / 12$ & 0.0 & 0.0 & 0.0 & 21.2 & 52.0 \\
\hline $17 / 12$ & 8.0 & 14.0 & 3.0 & 15.0 & 49.0 & $16 / 12$ & 7.0 & 0.0 & 1.0 & 14.8 & 49.0 \\
\hline $24 / 12$ & 5.0 & 4.0 & 4.0 & 15.1 & 53.0 & $23 . / 12$ & 27.0 & 5.0 & 3.0 & 15.3 & 56.0 \\
\hline $31 / 12$ & 1.0 & 3.0 & 6.0 & 16.3 & 58.0 & $30 / 12$ & 10.0 & 2.0 & 0.0 & 16.8 & 54.0 \\
\hline $7 / 1 / 013$ & 9.0 & 2.0 & 4.0 & 15.2 & 57.0 & $6 / 1 / 014$ & 7.0 & 1.0 & 1.0 & 14.7 & 58.0 \\
\hline $14 / 1$ & 9.0 & 7.0 & 5.0 & 15.1 & 54.0 & $13 / 1$ & 28.0 & 1.0 & 3.0 & 14.1 & 57.0 \\
\hline $21 / 1$ & 11.0 & 4.0 & 22.0 & 14.6 & 52.0 & $20 / 1$ & 15.0 & 0.0 & 0.0 & 13.3 & 62.0 \\
\hline $28 / 1$ & 13.0 & 2.0 & 2.0 & 13.4 & 53.0 & $27 / 1$ & 8.0 & 0.0 & 2.0 & 14.0 & 51.0 \\
\hline $4 / 2$ & 25.0 & 0.0 & 4.0 & 14.7 & 48.0 & $3 / 2$ & 0.0 & 0.0 & 0.0 & 16.8 & 51.0 \\
\hline $11 / 2$ & 19.0 & 0.0 & 12.0 & 13.0 & 45.0 & $10 / 2$ & 6.0 & 4.0 & 2.0 & 16.5 & 57.0 \\
\hline $18 / 2$ & 19.0 & 0.0 & 29.0 & 19.5 & 49.0 & $17 / 2$ & 9.0 & 5.0 & 6.0 & 14.5 & 50.0 \\
\hline $25 / 2$ & 14.0 & 0.0 & 24.0 & 17.8 & 50.0 & $24 / 2$ & 11.0 & 1.0 & 10.0 & 16.5 & 45.0 \\
\hline $4 / 3$ & 11.0 & 3.0 & 25.0 & 16.9 & 53.0 & $3 / 3$ & 19.0 & 4.0 & 1.0 & 15.5 & 49.0 \\
\hline $11 / 3$ & 9.0 & 2.0 & 33.0 & 22.9 & 49.0 & $10 / 3$ & 22.0 & 0.0 & 0.0 & 17.2 & 49.0 \\
\hline $18 / 3$ & \begin{tabular}{|l|}
17.0 \\
\end{tabular} & 0.0 & 9.0 & 21.1 & 52.0 & $17 / 3$ & 51.0 & 2.0 & 0.0 & 16.3 & 51.0 \\
\hline $25 / 3$ & 11.0 & 0.0 & 2.0 & 16.9 & 51.0 & $24 / 3$ & 25.0 & 2.0 & 0.0 & 18.8 & 50.0 \\
\hline $1 / 4$ & 5.0 & 0.0 & 0.0 & 18.5 & 488.0 & $31 / 3$ & 0.0 & 0.0 & 3.0 & 18.2 & 49.0 \\
\hline Total & 175.0 & 51.0 & 196.0 & - & - & - & 28.01 & 41.0 & 37.0 & - & - \\
\hline
\end{tabular}




\section{REFERENCES}

Berry, M. (1995): Herbal products. Part 6. Chamomile. (Pharmaceutical J., 254, 191-1 93).

Conti, E. (2003): Insects of common chamomile, Matricaria chamomilla In Book chapter; Conference paper (Pagiotti,R. and Poli, F. editors) Atti del convegno: Prospettive di produzione e di impiego delle piante officinali: la camomilla, San Sepolcro (AR), Pistrino (PG), Italia, 19 20. magio 2003/2004 pp.111-128. http://www.cabdirect.org/search html.

El- Gendi, S. S. M. (1988): Ecological and biological studies on some insect pests of ornamental and medicinal plants. Ph.D. Thesis Fac. Of Agric., Cairo Univ.

El- Gendi, S. S.M. (2007): Survey of insects in marjoram and chamomile cultivation in Fayoum and the relative abundance of the most dominant species. (Fayoum J. Agric. Res. and Dev., 21(1): 39-54).

El-Dessoki, S. A. ;A. H. El-Kifl and H. A. Helal (1976): Life cycle, host plants and symptoms of damage of the tomato bug, Nesidocoris tenuis Reut. (Hemiptera- Miridae), in Egypt. (Zeitschrift fur pflanzenkranKheiten und Pflanzenschutz, 83(4): 204-220).

Etman, A.A. M.; A.H. El-Hemaesy; M.A. Hanna and S.S.M. El-Gendi (1990): Ecological studies on the mired bug. Nesidicoris tenuis Reut. and the Lygaeid bug, Nysius cymoides Spin, on certain medicinal plants at Fayoum. (Fayoum J. Agric. Res. and Dev., 4 (2): 53-69)

Foster, H. B., H. Niklas and S. Lutz (1980) Antispasmodic effects of some medicinal plants. (Planta medica, 40, 309-319).

Gardiner, P. (1999): Chamomile (Matricaria recutita, Anthemis nobilis). (Longwood herbal task force P21)

Rahil, A. A. R. (2005): Mites and marjoram and chamomile cultivation in Fayoum and the relative abundance of twenty six species. Arab Univ. (J. Agric. Sci. Ain Shams Univ., Cairo, 13(3): 1033-1046).

Redei, D. (2007): True bug (Heteroptera) assemblages of medicinal and aromatic plants. Ph.D. thesis Depart. Entomol., Corvinus Univ., Budapest, Hungary.

SPSS. (2000): SPSS for windows, release 11. User's guide. SPSS, Chicago

Yarmand, H., S. E. Sadeghi; M. Mohammadi; S. S. Ebrahimi and A. R. S. Allahi (2006): Survey of arthropods associated with range medicinal plants in Tahran, Ghazvin and Isfahan provinces. (Iranian Journal of Forest and Range Protection Research, 3 (2): 107 - 128). 


\section{حصر و تذبذب التعداد للآفات الحشرية والمفترسات الثائعة على نوعين من النباتات الطبية في محافظة الفيوم - مصر ربيع حسن عوض سليمان النيان قُم وقاية النبات ـ كلية الزراعة - جامعة الفيوم}

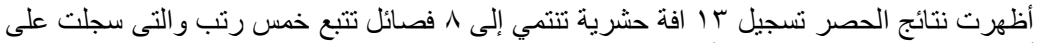

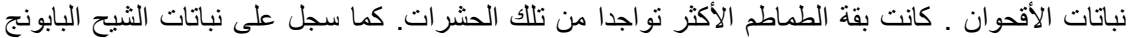

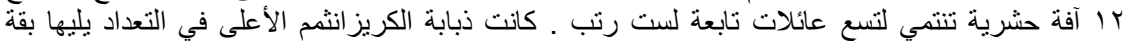
Nysius graminicolus K g Lygus gomellatus H. S.

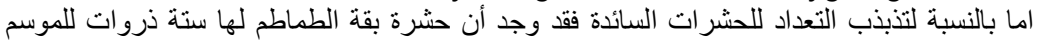

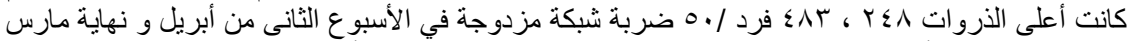

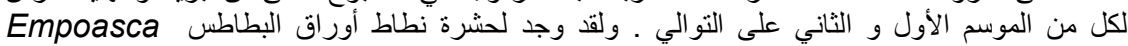

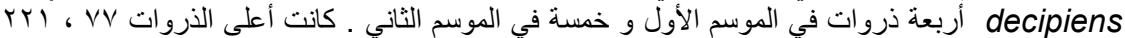

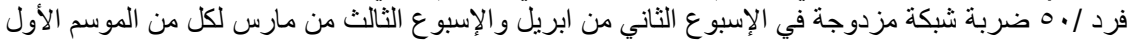
على الثيح البابو نج سجت حشرة Lygus gomellatus خمسة ذروات في الموسم الاول

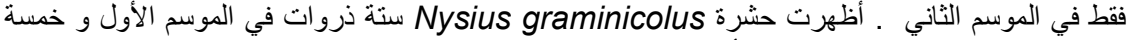

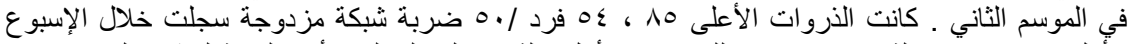

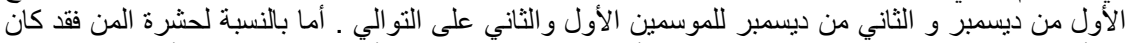

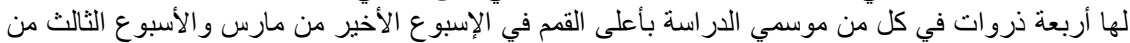

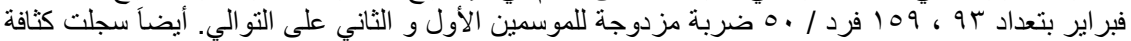

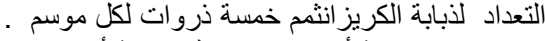

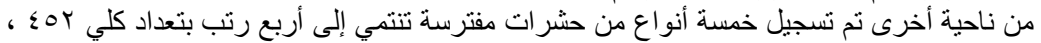

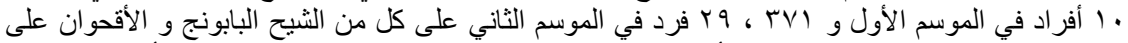

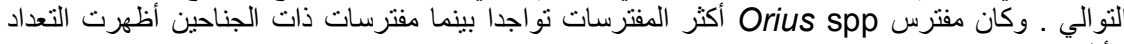

